\title{
The Feasibility of Democratisation in Sub-Sahara Africa: A Study of South Africa after the Apartheid System
}

\author{
Moshood Saka ${ }^{1}$ \\ Department of Political Science and Public Administration, Faculty of Social Science, \\ Al-Hikmah University Ilorin ${ }^{1}$ \\ sakaayoka@gmail.com ${ }^{1}$
}

\begin{abstract}
This article explores the scholarly ideas of Clauda Ake in his book 'Feasibility of Democratisation in Africa'. Democratisation is feasible as government focuses on the real people irrespective of racial affinity. In the past, the apartheid government in South Africa was judged as an obstacle to democracy because majority of Blacks were marginalised in the representative democracy. The African National Congress (ANC) developed a pressure against undemocratic laws of apartheid rule. This process translated to Trust Reconciliation Commission (TRC) as a driving-mechanism towards peaceful negotiation in the country. While this is true, this article argues that transition to democratisation in 1994 by founding elections marked the beginning of a representative government. This article contests the current practice of democratisation by political disconnection of the popular party after the death of President Nelson Mandela. Finally, it is argued that the feasibility of democracy is economic empowerment of the people but was trivialised in the country. The article further states the characters which marred democratisation process after the postthird wave. The article posits that there were adequate oversight functions which checked the excess powers of the executive arm and the others. This fact is justified by the action of opposition parties such as Economic Freedom Fighters (EFF), Democratic Alliance (DA), and Inkhatha Freedom Party (IFP) in the Freedom House. As a result, triangulation politics is recommended as mechanism which can promote national unity in the country.
\end{abstract}

Keywords: Democratisation, legitimacy, competition, political party, apartheid, and electoral system 


\section{Introduction}

The process of democratisation is a global network as operation emasculates the authoritarian regimes for democratic governance in the $21^{\text {st }}$ Century. However, the rationale which informs this process is succinctly determined by overall events such as the Fall of Berlin Wall in 1991, End of Cold War 1990, and the freedom of Nelson Mandela in 1990. These altogether reflected historical end of dictatorship in global politics. The aforesaid events have informed democratic movements against autocratic supporters in the state (Fukuyama 1992: xi-xii). Meanwhile, the interest of African countries in governance largely respond to democratic leaders in liberating their people on representative democracy in this millennium (Bratton and Van de Walle 1997: 159-160). This is necessary for measuring the legitimacy of democratic government by the electorates that organised the sovereign government. South Africa is a focus in the study of African democratisation process and this practically informed the issue of governance after the post-third wave. Why South Africa in this era? The country is diversely surrounded by multinational political groups collectively known as a rainbow nation. Rainbow nation connotes ideology of racial affinity on one hand, and also defines citizenship from the historical perspective on the other hand (Nattrass 2014: 12-13).

The historical perspective reflects the country as a multinational society estimated at 52 million people derived from the features of Ama-Zulu, Ama-Xhosa, Aba-Swati, Ama-Venda, Ama-Iswana, Abe-Suthu, Africaans, English, Ndebele, Tsonga, and AbaPedi. The three common languages are: English, Afrikaner, and Zulu. Historically, the country is important in the South African Development Community (SADC) because the component of people which dominated the political space are White, Black, and Indian. In the past, the country was governed by the White minority including the Indian and coloured that controlled the political and economic power under the structure of apartheid. The emasculation of apartheid system, therefore, led to the rise of representative government in 1994 (Ginburg 1996: 77-78). However, the construction of deliberative democracy opens a new representation and competition among different political groups. Each political group abided by the rules and regulations of the democratisation process based on the principles of free and fair elections. Meanwhile, the social relations of multinational society is to work towards a nation-building in connection with socio-economic development, which improves upon the expectations of people in the country (Grugel 2002: 3-9).

Campaign promise leads to socio-economic development as the key expectations of people are guaranteed by leadership performance. In the practice of South African politics after the demise of apartheid, deliberative democracy confronts economic choice between capitalism and socialism. The acceptance of socialism by majority blacks served as a policy which can bridge the gaps between the rich and poor in the 
country. President Mandela, after his vindication, announced that nationalisation will be instrument which can address the question of socio-economic disparity (Atuahene 2014:170-172). Apart from this, management control of the private enterprises should be foreign investment as compensation in the country. In addition, the government acquisition of the private sectors is an element of deregulation of the economy (Nattrass 2014: 3-4).

Turning to the practice of representative democracy after the post-apartheid for procedural arrangement promotes the deepening of governance. The discussion between De Clark and Nelson Mandela on the key practice of universal adult suffrage for selection of leadership is cogent to human rights. The formal President De Clark mentioned that democratic arrangement in the country will lead to total majority abusing the rights of minorities, and this exercise will practically result in domination of one political group against the others. Instead, there should be a preference for power-sharing that can protect the minorities' interests. The National Party (NP) and the African National Congress (ANC) are deliberately maintained for peace process in the formation of Truth Reconciliation Commission (TRC) (Clark and Worger 2004:102-104). The importance of TRC was for the creation of a new sovereign government against the apartheid regime. On this ground, the electoral system was opened for overall participation and competition of the people to select leadership. Therefore, the formation of Inkatha Freedom Party (IFP) has equally increased the level of political opposition in the country (Nattrass 2014: 21).

The practice of democratisation started by founding elections in South Africa in 1994. The elections saw an unprecedented turnout of the multinational groups participating in deliberative democracy. Deliberative democracy nationwide triumphed over the majority political groups, which tended to marginalise minority groups under the apartheid system. In this practice, there will be a balance of democratic power among the contending political parties for the constituent positions vis-à-vis legislature, executive and a host of others (Ginsburg 1996: 74-75). The environment of South Africa is a theatre of racial groups where each group supports moral ethnicity. The norm of moral ethnicity undermines democratisation process after the post-third wave in the country. The evidence has shown in the successive elections as racial competition and participation (Seo 2008: 3-4). At this juncture, leadership in South Africa is usually organised under the participation and competition of the political stakeholders such as the electorates, governing elites, non-governing elites, and the civil society groups. The electorate's votes have made the contestation more intensive in the political space. The operation of multiparty system in the country makes representative government opens to the people. In the competition and participation, the political space developed a single political party domination. Recently, the African scholars have queried the practice of presidential system of government on personality of leadership against the element of alternative power. It 
practically means that the central power (presidency) requires the control of the ANC and the opposition parties are struggling to change the power (NIC 2008: 1-2) but failed in the successive contestations.

Apart from this practice, the practice of leadership in African government could be distilled into three general characteristics: first, ethnic morality means socioeconomic and political sentiment against other political groups. Second, prebendalism and neopatrimonial are abusive use of the state resources by directive of the political leaders who act in the interest of political group (Orvis 2001: 27). Lastly, patron-client-networks juxtapose the first two practices by excessive employment, political position, even when the clients (political supporters) are not qualified for position but they are enlisted in the social opportunities by patrons (leaders). In view of this norms, Grugel (2002: 69-72) confirmed that African democratic norms started from elections as the procedures were unfair and corrupt. For example, Ghana, Nigeria and Tanzania after transition to democratisation, the successive elections caused other problems. The power of incumbent president in Africa used funds to dispense patronage and give civil servants pay rise in order to win votes of the electorates. It supports the expression of Bratton and Van de Walle (1997: 61-69) that the principle of authority and power is dint by the personal prestige and power. This politics is treated as an extension of big man's politics. The successive elections in Africa are generally depicted as empty and largely symbolic exercise designed to legitimate officeholders. And, indeed, following a long competitive election at independence, that is, apparent what many African elections became. Similarly, the new democratic states in Africa are largely divided by multinational political groups. According to Jinadu (2015: 6),

\begin{abstract}
"To understand the character and trajectory of ethnic conflict in Africa, we must situate it in broader context of the democracy and development project on the continent. That project is primarily concerned with the state-building or stateformation process, which characteristically involves or generates hegemonic-directed competition, cooperation and conflict, under conditions of scarcity about who should control the state and direct its core functions of authoritative regulation, allocation, and distribution through its presumed monopoly of physical force and policy directive"
\end{abstract}

It is true that South Africa is unique in diversity of multinational society. This feature makes the participation resemble cultural affinity. However, the majority and minority political groups in the country are to select leadership among the contesting political parties as it would inform overall political development. Therefore, it is in this sense that democratisation process is moving toward the deepening of democracy after the founding election in 1994 (Grugel 2002: 17-19). Apart from this 
analysis, the country is virtually dedicated to an overall policy that could improve upon the general expectations of the people irrespective of the cultural affinity. As a matter of fact, democratisation process faces several political challenges in heterogeneous societies. Generally, transformation of the political system from nondemocracy towards accountable and representative government is a process of democratisation (Huntington 1991: 121). Other questions are posted about what the people demand for, and how do they know if a government expresses it? What are the limits of the state on individual freedoms? When do people morally comply to obey law with which they do not agree, and when can the coercive power of the state be employed legitimately? The contextual argument of political power is only proper when it is exercised in accordance with the constitution of the state (Vanderveen 2007: 243-244).

\section{Democratisation Process}

The transition to democratic governments in Africa was constructed from practical events unlike the European transition process. The European transitions to democracy were initiated by revolution led by political reformers. This translated to actions which paved the way for socio-economic development which removed social injustice in the states. In that era, the authoritarian regimes were administered by authority of the monarch that has absolute power. On the other hand, the process of democratisation in Africa was established through extrication and replacement of the authoritarian regimes for democratic rule. The method of replacement in South Africa was a unique process because it takes several negotiations between undemocratic leaders and political reformers (Huntington 1991: 142-143). Therefore, South Africa adopted negotiation as a reactionary policy for political development. The issue of marginalisation of a political group in the participation and competition was resolved by Truth and Reconciliation Commission (TRC (Clark and Worger 2004:89-90).

The condition which promotes the smooth process of democratic transition in South Africa was involvement of political synergy which paved the way for the establishment of the TRC. The new development serves as an instrument of building unity in the multinational political groups. The general admission of each political group was that the ideology of apartheid was a crime against the humanity and gross human rights violation (Gibson 2006: 400). The new political arrangement was centred on four dimensions: (1) inter-racial reconciliation and of any form of prejudice; (2) political tolerance of one another in the contestation and participation; (3) support for human rights principles and equality before the law against submission under one race; and, (4) the extension of legitimacy to political institutions vis-a-vis parliament and the Constitutional Court to discuss legal matters in the country without prejudice (Clark \& Worger 2004:88-93). The significance of the TRC was further extended to the ordinary citizens to participate in the leadership selection on the process of electoral rights (Gibson 2006: 412-413). As a result of this, citizens will have confidence to 
enjoy constitutional rights such as movement, assembly, religion, politics, and a host of others without racial subjugation.

Apart from these fundamental issues, other things about the TRC should be noted. First, the process must have national outlook in forming a broad-based unity among the people as it informs recognition of one another. The practice of apartheid before was not favourable to any party in the country but incorporated suffering for everyone and should be condemned by every citizen in the country. Second, the TRC was a political dialogue that removes social character and introduces new political wills in the country. Lastly, liberalisation and democratisation start when the overall people are committed to participating in the representative government. The action will deliberately resolve the past issues in the present for the future politics. Therefore, the political stakeholders will generally condemn the belief and nostalgia attitude of racism for practice of democratic government and the deepening of democracy. Racial discrimination as a practice of governance cannot improve the productivity of life except when adequate deliberative representation is enmeshed in the deepening of democracy and perfect consolidation of the government (Gibson 2006: 420-426).

As previously mentioned, political negotiation was a policy framework which reshaped the political environment. It also organises new contestation and participation against the element of marginalisation of the Blacks by autocratic government of the past. The establishment of the modern state in South Africa was a process of compromise and concession adopted by the ANC to restructure the political environment. This political approach will ventilate on peace process that would not transpose to violence. Apart from this approach, the country has not experienced a revolution in the process of democratisation but a negotiation which forged all the political elites (Lee 1997: 74). However, if the majority of Blacks promoted radical changes, there would have been a total destruction of lives and property. The outcome of this would have been total damage to the economic and political structure. In the peace process, thus, the political entity has remained intact with effective democratic structure; perhaps, an agreement was reached by the Black majority to cooperate with the white and other minority groups in the country. In addition to this development, the economic structure of the country remains intact, which means that white economic entrepreneurial control over the banking industry, financial market, and other industries are not disturbed (Lee 1997: 80-83). The global trend on campaign for human rights and human dignity anywhere and elsewhere is improved upon in the country. The period between 1985 and 1994 were periods of political debate which translated to the vindication of Nelson Mandela from prison by the agitation of ANC as the leading civil society organisation in South African Development Community (SADC). Over the years, human rights movement was the unifying policy of the United Nations. This ideally intensified the political struggle between the National 
Party (NP) as the ruling party then, and the African National Congress (ANC) as the reactionary pressure group (Wilson 2001: 5).

At this juncture, transition to representative government took a mature understanding between the two political parties in addressing the central issues in the country. Particularly, the rights of majority political group which was marginalised over decades can be resolved by negotiation. Part of the negotiation was the peaceful talk which focused on review of the constitution on national matters in 1993. After the negotiation between the NP members and the ANC supporters, there was political violence. The political violence in South Africa was an aberration before the transition from apartheid system to democracy. The form of violence was recorded such as targeted killings or hit has increased across the country. Political environment is also described as violent because of social inequality between the White minority and Black majority. The youths were recruited across the country to participate in the violence (Dawn 2008: 2-4). In view of these analyses, social inequality translates to moral ethnicity such as inequality in standard of living, income/wealth, education, health, nutrition, opportunities, and employment (UNDP 2013: 16-17). In the end, the new constitution was drafted in December of the same year. These political activities changed the lives of the people in the country (Wilson 2001: 7-10).

The role of unions in the struggle against social labour was characterised by injustice in the apartheid rule. The trade unions have been at the forefront of struggle for a new leadership. A number of trade unions were established. One of such is the National Union of Mineworkers (NUM), which serves as medium education for industrial workers. Unionism is also seeking to redress vapid employment conditions, including those of rural areas labour under the authoritarian government (Anyaoku 1991:-59-62). However, the mineworkers were challenged by inadequate trained staff who lacked formal education. The industrial workers were supported by a vibrant civil society, which were effective in the struggle against authoritarian regime of the past (apartheid). This political attitude emerged from the enforcement of draconian law of the land that worked against the industrial workers (Anyaoku 1991:-56-57). Therefore, the expectation of the union is economic reform and this demand could be addressed in a representative democracy. Meanwhile, the internal joint movement articulated over 12,000 oppressed workers for the solidarity movement in Cape Town as they were agitating for justice in 1983. The poor conditions of service have motivated the workers to form an effective pressure group against authoritarian policy of the ruling party (Swilling 1987:192-193). However, the formation of United Democratic Front (UDF) has equally empowered the workers against the autocratic system. Therefore, the total hatred for apartheid rule also paved the way for social justice movements in the country, which included associations such as: Church members, women groups, youths and students organisations, sporting clubs, and professional bodies with an estimated total membership of one million members. 
These civil society groups convergence to form a strong national resistance against the authoritarian regime in South Africa. Other rebellions was also recorded in Soweto with reference to pressure groups against autocratic rule (Swilling 1987:195).

\title{
3. Feasibility of Democratisation
}

Institutional performance is the inherent process for measurement of democratisation with emphasis on character and reform. In the real sense, feasibility of democratisation is a far-reaching practice in the electoral system as well as socioeconomic policy of the government. Therefore, the feasibility of democratisation is related to institutional performance with practical emphasis on democratic leaders committing to deepening of democracy. Institutional performance also recognises the responsibility of electoral commission in conducting credible elections in the country. Meanwhile, the electorates have the power to choose according to their choices in the leadership selection. According to Huntington (1991: 174),

\begin{abstract}
"Elections are the way democracy operates. In the third wave they were also a way of weakening and ending authoritarian regimes. They were a vehicle of democratisation as well as the goal of democratisation. Democratisation was brought about by authoritarian rulers who, for one reason or another, ventured to hold elections, and by opposition groups who pushed for elections and participated in them. The lesson of the third wave is that elections are not only the life of democracy; they are also the death of dictatorship"
\end{abstract}

The founding elections (transition elections) were conducted across some African countries for the first time after the collapse of the authoritarian regimes. In this process, the autocratic government in South Africa was removed by contested elections in 1994. The outcome of the election was free and fair in the democratic history of the country. One of the features of the election was that the opposition parties accepted the result as well as the international observers that developed the process of further elections in leadership selection. As a result of this, the election was conducted under multiparty system with the victory of the ANC in the presidency and legislative arm. Therefore, Nelson Mandela was sworn in as the first executive president in 1994 (Bratton and Van de Walle 1997: 196).

Multiparty system also recognises the orderliness of the electoral process as a process of selecting leadership in a multinational society. The element of party system involves adequate practice between the elites and the electorate to establish a government with national interests basically on leadership performance. Therefore, the core principle of party system complies with the elements of democratisation of culture such as accountability, transparency of leadership and spirit of tolerance. The interest of the people should be the priority in the state. Furthermore, party system 
is an instrument of training, recruitment, information and mobilisation of the electorate for leadership selection in a democratic state (Saliu 2010: 48-52). The feasibility of democratisation in South Africa also reflects the elections of 2004 and 2009. Both elections have improved upon the corporate existence of the multinational groups. In the preceding electoral years, the political behaviour of the citizens was saturated on the level of competition and participation of the people. The electoral outcome remarkably reflected the deepening of democracy despite severe challenges in the country (Gill 2000: 87-89).

Table1: 2004 and 2009 Election Results

\begin{tabular}{|c|c|c|c|c|c|c|}
\hline Political Party & $\begin{array}{l}2004 \\
\text { Score }\end{array}$ & $\%$ & Seats & $\begin{array}{l}2009 \\
\text { Score }\end{array}$ & $\%$ & Seats \\
\hline $\begin{array}{ll}\text { African } & \text { National } \\
\text { Congress } & \end{array}$ & $10,878,251$ & 69.7 & 279 & $11,650,784$ & 65.9 & 264 \\
\hline Democratic Alliance & $1,931,201$ & 12.3 & 50 & $2,945,829$ & 16.7 & 67 \\
\hline Congress of the People & - & - & - & $1,311,027$ & 7.4 & 30 \\
\hline Inkhatha Freedom Party & $1,088,664$ & 7 & 28 & 804,260 & 4.6 & 18 \\
\hline Independent Democrats & 269,765 & 1.7 & 7 & 162,915 & 0.9 & 4 \\
\hline $\begin{array}{ll}\text { United } & \text { Democratic } \\
\text { Movement } & \end{array}$ & 355,717 & 2.3 & 9 & 149,680 & 0.9 & 4 \\
\hline $\begin{array}{l}\text { African } \\
\text { Democratic Party }\end{array}$ & 250,272 & 1.6 & 6 & 142,658 & 0.8 & 3 \\
\hline Freedom Front Plus & 139,465 & 0.9 & 4 & 146,796 & 0.8 & 4 \\
\hline $\begin{array}{l}\text { United Christian } \\
\text { Democratic Party }\end{array}$ & 117,792 & 0.8 & 3 & 66,086 & 0.4 & 2 \\
\hline Minority Front & 55,267 & 0.4 & 2 & 43,47 & 0.3 & 1 \\
\hline $\begin{array}{ll}\text { African } & \text { People } \\
\text { Convention } & \end{array}$ & - & - & - & 35,867 & 0.2 & 1 \\
\hline Pan Africanist Congress & 131,512 & 0.7 & 3 & 48,530 & 0.2 & 1 \\
\hline New National Party & 257,824 & 1.65 & 7 & - & - & - \\
\hline AZAPO & 41,776 & 0.5 & 2 & 38,245 & 0.2 & 1 \\
\hline
\end{tabular}

Source: (Kersting, 2009: 129)

The table above reveals that there was a party system in the selection of leadership and the system ventures into multi-party system. However, the observation of 2004 and 2009 elections in this study gives broad analysis of the representation in the country. Apart from the electoral results, between 2004 and 2009, fourteen political parties contested to ensure that they capture the procedural votes of the electorates. In the process of leadership selection, each political party targets the electorate's votes in the representation for the legislative arm of government. Therefore, it was also observed in the table that the representation fluctuates based on the electorate's 
choices of the two years. The turnout in South African elections was unprecedented because the exercise was free and fair in the operation of civic rights. This electoral process starts from the campaign promises as the elites present their manifestoes to the public. The outcome of election in South Africa is always under the drawing board of multiparty electoral system (Kersting, 2009: 102-106). This system frequently accommodates new and old political parties which are duly registered by Electoral Commission of the country. With regard to the 2004 and 2009 elections, both elections were astronomically won by the ANC in leadership representation.

\section{Challenges to the Democratisation Process}

The democratisation process in Africa is necessary on the grounds that assessment is recognised by campaign promises and leadership performance. In the real practice, the actions and characters of the overall stakeholders in establishing representative institutions always co-opt with democratisation of culture (Bratton \& Van De Wale 1997: 234). It is at this juncture that this study discusses the challenges to democratisation in the country. Therefore, this study focuses on certain issues in the politics of the country which practically challenged the process of democratisation after the demise of authoritarian regime in 1994. This is the process of assessing democratic challenges which highly affected good governance. There is the need to explain with scholarly literatures which confirmed South African democratic project as hegemonic of one ruling party. ANC, as the popular party, members are basically frustrating the principles of democratic consolidation particularly in the area of power change to opposition parties. The process of democratic consolidation is synonymous with alternation of the electoral power. The evidence of centralization of power by the popular party is obvious at every successive election vis-a-vis presidency, Legislative House and the local governments. This electoral outcome has rendered the opposition parties as ineffective in the electoral matters. Meanwhile, the leadership of hegemonic party has equally extended inter-party relations (decentralization) at all institutional levels such as floor-crossing, ward committees and oversight functions (Muriaas 2011: 1-3). However, there was party affiliation in the election conducted by the electoral commission (Masemola 2007: 7, Kersting 2009: 131). Therefore, this practice has dominated the political environment after the end of the apartheid government. According to Taylor and Hoeane (2007: 137) declared that:

Accepting the historic weight of apartheid, more analyses of the 1994 election concluded that the best way of interpreting that event was in terms of it being a straight racial census; with black voting for black parties (the ANC) and white voting white parties (NP and DP). And since 1994 many commentators and analysts have continued to accept the centrality of racial and ethnic identities as laid down in the 
apartheid-era categorization. What this means is that political parties are seen to have racially defined supported bases with it being held that, as the ANC continue to capture the black votes, such pattern will require a long time to be broken down, having very negative implications for the consolidation of democracy. Thus in 1999, for opposition parties, the need to strategize in terms of logic of racial arithmetic was 'self-evident.' And in turn, the election results were widely interpreted to confirm racial and ethnic bloc voting

To justify the outcome of 1994 contestation and participation, however, the international and local observers have reported that political behaviour was determined by racial census. The electoral outcome was never new to the commentators on the field because of the perennial character of the apartheid rule. After transfer of power to the opposition party (ANC), there was quick policy to recover socio-economic development in the country. In fact, campaign promises was neither delivered nor reflected the interest of the Black majority. Part of evidence was the rating of the tenure of President Mbeki and President Zuma that were both assessed as low leadership performance as declared by the people (Hamill 2010: 7). The ANC did not deliver on their campaign promises and leadership performance of the ANC was ineffective on the people. The growing of unemployment and poverty was an aberration in every successive government. The country has recorded jobless people in 2010 and the unemployed people constitutes a social and political challenge for the ANC government. Statistically between 1994 and 2014, the unemployment rate was classified according to the race groups such as Black African $43 \%$, Coloured $24 \%$, Indian $18 \%$ and White $8 \%$ respectively. The numbers of unemployed have increased for all race groups (Statistics South Africa 2015: 33). In addition to this evidence, poverty level in the country was uncontrolled as citizens lived above the poverty line (Shapiro and Tebeau 2011: 18-20). Some African countries lived below and within the poverty depending on the rate of dollar. The first three governments led by the ANC after 1994 promised to tackle the challenge of poverty and inequality they inherited from authoritarian regime of the past. Consequently, the expansion of poverty and unemployment in the early 2000s thus continued to grow along a path that is unfriendly with the poor people in the country (Shapiro and Tebeau 2011: 21). In the foregoing, after the fall of authoritarian regime in 1994, the economy was not favourable to the majority political group. So, the demand for economic policy which could solve the current challenges was put in place at exigency period. Some of the challenges are: unemployment, poverty, crime, and poor education (Cheteni et al 2018: 3-7). Some political analysts believed that these problems were switched over from the era of apartheid. However, resolving it would take a long time. Perhaps, the policy framework that was established by ANC party is to reduce the intensity of the problems. However, this study commends the legacy of President Mandela as an exemplary leader for humanity across the world. His philosophy transparently reflected social relations that improves upon the expectations of the people in the 
country. After his death, the predecessors have ignored his philosophy for undesirable personal interest in political power. For example, there was a high struggle for the post of presidency which thus has led to pervasive corrupt practices in the public sectors being recorded (Pillay 2004:586-589).

The government has equally established a policy that would check this character in the public sectors. This transparently led to the establishment of South African AntiCorruption Programme in 1997 and the adoption of Anti-corruption Conference in conjunction with the United Nations (UN) in 2003. There are some of the efforts put in place in controlling the problems. In addition, one of the major causes of problems in the successive governments is weakness of the public institutions under the control of the ANC. A case of corruption was reported by Reddy (2007: 51-52) on the allocation of funds to HIV/AIDS scheme in the country. The funding scheme was provoked by poor services rendered to the National Association of People Living with Aids (NAPWA). This form of corruption is illegal withdrawal of funds allocated to the infected patients account. For example, the case of misappropriation was recorded in 1996 with the then minister of health Nkosazama Dlamini-Zuma failed to account for R14 million funds allocated to the Aids patients. Similarly, a corrupt case was also levelled against President Zuma's prodigal spending on his private house with public funds for Nkkandla. The issue generated political division in the Legislative House. Therefore, opposition members in the Freedom House have called for repayment of the public funds (Reddy 2007: 53-55). This oversight arrangement was accepted by all the parliamentarians including the ANC in the Freedom House.

Transition to representative democracy is a collective effort of the political stakeholders as the defenders are cooperating to surrender power to the opposers in a multinational society. The nature and pattern of politics in the heterogeneous society is determined by political interplay. In the real sense, the multiparty system allows each political party to select a candidate to contest power. Therefore, electoral power is usually limited to certain constituent offices and it make struggle more intensive in the state. It also makes the contestation and participation to reflect characters which are either desirable or undesirable (Huntington 1991: 52-56). In this view, struggling for power in a new democratic government by the multiparty system is inevitable to political conflict. It is true that, there has been recurrent interparty conflicts between the ANC and Inkatha Freedom Party (IFP) in the contestation for power over the years. These forms of conflicts are in various degrees depending on the character that transpose to acrimony. This usually occurs after the emergence of IFP in the electoral system. There are sequence of attacks and killings in the country. The IFP was labelled as a political rival to the ANC and this political acrimony affected the electoral system particularly in some few provinces (Bruce 2013: 1315). Various political killings which increased from the 1990s onwards are generally appeared to be deliberate killing of the political opponents. Political acrimony also 
manifests in members of rival political parties. For example, in Kwazulu-Natal province between 1994 and 1996, 220 people were reportedly killed and many seriously injured. Additionally, between 1996 and 1999, some areas that were affected in the acrimony such as Wembezi near Estcourt in the northern Midlands and Umlazi areas were points of political killings. These political attacks resulted in the killing of the party leaders of ANC and IFP in 2011 and 2012 (Bruce 2013: 17-20).

\section{Sustainability of Democracy and Democratic Consolidation}

The sustainability of democratisation emphasises on the process of democratic government as it informs the ethical practice of democracy. Representative institution in the country produces public criticism as oversight functions in the Freedom House. This pressing argument is captured by You Tube in 2015 as entitled: Jacob Zuma shouting at Mmusi Maimane, a delegate member from DA. In this political character, the political commentators observed that there is scrutinization of leadership on performance by legislative oversight. The available evidence which recognises the actions of President Jacob Zuma answering queries that affect the country. Apart from this issue, other episodes which also informed the question of Nkandla are discussed and the president was publicly rebuked mostly by the opposition parties in the parliament insisting on repayment of money (Karodia and Sona 2016: 2527). However, the oversight function is an approach towards the checks and balances among the legislative, executive and judiciary arms of government. The element of checks and balances also improves on the quality of democracy in term of transparency and accountability in public institutions (Sachikonye 2002: 3-10). The institutional framework in South Africa often demonstrates a remarkable improvement on public issues which openly reflected political system. In this system, the interaction of the three arms of government have equally justified the effectiveness of the operation vis-à-vis legislative, executive and judiciary including the civil society groups. The practice from 1994 to the present, successive governments have established and implemented various sustainable developmental plans for ensuring magnanimous goals in the country (Sachikonye 2002: 9-13).

Economic development is one of the core features which accommodate leadership performance of a democratic system. It basically reflected expectations of the citizens which come in form of dividends of democracy. In this connection, the argument is that sustainable development requires the empowerment of social groups, equity, co-operation and security in a particular country. Second, sustainable development should give priority to the poor rather than marginalise them, entrench the environment rather than derail it, and support women rather than separate them. Third, entrenching the process of sustainable development is to enhance perfect consolidation of the political system (Sachikonye 2002: 14). Therefore, it is not 
possible to attain high levels of participation and empowerment of the people. There is the need to remove high levels of illiteracy, unemployment, and gender inequalities. Lastly, the consolidation of democracy and good governance should simultaneously contribute to stronger foundations of sustainable development. As a result of this, the incumbent party and opposition parties in this process should accept the norms and values of good governance in order to transform socio-economic growth and development (Sachikonye 2002: 3).

Sustainability of democracy is determined by active practices of procedural legitimacy as a proper political arrangement after the post-third wave in Africa. The principal source of legitimacy is election which arranges for leadership selection under a multiparty system to establish government of the citizens (Huntington 1991: 52-54. However, legitimacy offers a broad function on performance of the political system and the electorates change power of the elites by their votes. Additionally, procedural legitimacy offers a weight to the principal power of the electorates to establish modern representative government. The practice relates with leadership performance of the party in power to deliver socio-economic expectations to the people. Thus, in this explanation, it is citizens that withdraw their political legitimacy from the government that failed the people. Similarly, it is the government in power that disconnects the citizens after the elections. Basically, political disconnection is viewed as inhuman, unaccountability, censorship, and human rights violation caused by the elites in power. According to Huntington (1991: 50),

The effort to base legitimacy on performance, however, gave rise to what could be termed the performance dilemma. In democracies, the legitimacy of rulers usually depends on the event to which they meet the expectations of key groups of voters, that is, on their performance. The legitimacy of the system however, depends on procedures, on the ability of voters to choose their rulers through elections. In office, the rulers, eventually fail to perform they lose legitimacy, they are defeated in the elections, and a different set of rulers takes over.

The electoral system maintains the process of democratic consolidation with emphasis on power change. Procedural legitimacy explains democratic reforms in the process of making democratic government more active in leadership performance (Whitehead 2002: 91). The concept of legitimacy is a pressing argument which mirror the theoretical explanations of scholars in an attempt at analysing the action and character of democratic consolidation. The government is legitimate only when it expresses the will of the people on socio-economic empowerment in the state (Huntington 1991: 54). As regard economic empowerment of the people, other mechanisms are feasibility of democratisation. Such as free and fair elections, ethnic 
tolerance, adequate checks and balances in the Freedom House and review of the constitution, altogether are principles that promote the deepening of democracy.

\section{Conclusion}

This study concludes that there is feasibility of democratisation in the Republic of South Africa such that the political arrangement is democratised by successive elections. However, the current challenge in the country is consolidation of democratic government based on the principles of procedural legitimacy (change of power) in the presidency. There is serious oversight functions in the Freedom House and the practice improves upon the failed government in power. Part of the character is questioning of the public office holders including executive arm of government on the basis of leadership performance. This magnificent improvement stems from the opposition parties supporting the people in different circumstances. The opposition parties have scrutinised the presidency by the oversight power in the parliament. Meanwhile, the country is designed on monolithic political party ANC, which occupies the political space since 1994 . The rationale in this process is that the political behaviour of the Black majority is clearly to maintain leadership that was lost under the apartheid government, which stayed for decades. Therefore, the study suggests triangular politics as the practice that could sustain as well as consolidate democratic government. The approach to new South Africa will promote national unity against ethnic morality that is pervasive in the political space. However, the practice of triangular politics was adopted in the European countries vis-à-vis the United States of American, France, British, and Canada. Thus, triangular politics and democratisation attempts at building national interest in the state as it recognises apparent use of the multinational groups in governance. It also means that the incumbent party should recognise the non-governing political parties in the areas of needs, which can benefit the entire people.

\section{References}

\section{Books}

Alexander, P. (2013). Marikana Turning Point in South Africa History, University of Johannesburg South Africa.

Atuahene, B. (2014). We Want What's Ours: Learning from South Africa Land Restitutions' Program, Oxford University Press.

Boehmerm, E. (2008). Nelson Mandela: A Short Introduction, Oxford University Press, New York.

Bratton, M and Van de Walle, N. (1997). Democratic Experiments in Africa: Regime Transition in Comparative, Cambridge University Press. 
Carbone,M.G. (2010). Do all Good Things Go Together? The Political, Economic and Social Consequence of Democratisation. University DealiStudi di Milano.

Clark, N.L. \& Worger, W.H. (2004). South Africa: The Rise and Fall of Apartheid. Pearson Education Limited.

Doh Chull, S. (2006). Democratisation: Perspective from Global Citizenries. Centre for the Study of Democratisation. University of California, Iruine

Fukuyama, F. (1992). The End of History and the Last Man. A Division of Macmillan, New York

Gill, G. (2000) The Dynamics of Democratization Elites, Civil Society and the Transition Process. Macmillan Press London.

Grugel, J. (2002). Democratization: A Critical Introduction. Palgrave New York Hamill, J. (2010). A (Qualified) Reaffirmation of ANC Hegemony: Assessing South Africa's 2009 Election, Routeledge.

Huntington, S.P. (1991). The Third Wave Democratisation of the Twentieth Century. University of Oklahoma: Norman London.

Lee, C.M (1997). Challenges Facing the Mandela Government. In Nngola-Ntalaja, G and Lee C.M (eds). The State and Democracy in Africa, Books, Harare Zimbabwe Martin,M. (1997). South Africa: Time of Agoni, Time of Destiny: The Upsurge of People Protest. Verso London.

Menocol, R.A, Fritz, V, and Rakner, L. (2007). Hybrid Regime and Challenges of Deepening and Sustaining Democracy in Developing Countries. Wilton Park Conference on Democracy and Development in October, pp.10-12.

Muriaas, L.R. (2011). The ANC and Power Centralization in South Africa: Does Local Democracy allow for Power Sharing? www.researchgate/publication

Nattrass,N. (2014). South Africa Post-Apartheid Democracy and Growth. Centre for Development and Enterprise.

Ndegwe, S.N. (2001). A Decade of Democracy in Africa: International Studies in Sociology and Social Anthropology. Leiden, Boston. Koln

NIC (2008) Democratisation in Africa: What Progress towards Institutionalization. Ghana Centre for Democratic Development.

Orvis, S. (2001). Civil Society in Africa or African Civil Society. In Ndegwa N. Stephen (eds.), A Decade of Democracy in Africa. (19-38). Leiden, Boston. Koln

Reddy, T. (2007). A Lethal Cocktail: Exploring the Impact of Corruption on HIV/AIDS Preventing and Treatment Efforts in South Africa, Transparency International Zimbabwe. 
Sachikonye, L.M. (2002). Democracy, Sustainable Development and Poverty: Are they Compatible, Development Policy Management Forum (DPMF).

Sadurski, W. (2006). Law Legitimacy and Democracy-Plus. Oxford University Press, pp. 377-409.

Saliu, H. (2010). Democracy, Governance and International Relations. College Press and Publishers Limited, Lead City University

Seo,S. (2008). A Study on Democratic Transition of South Africa: Democracy through Compromise and Institutional Choice, Department of Literature and Philosophy. University of South Africa.

Shapiro, L and Tebeau, K. (2011). After Apartheid: Reinventing South Africa. University of Virginia Press, Charlettesville and London.

Statistics South Africa (2015). Unemployed, Unemployment, Skills and Economics Growth. An Exploration of Household Survey evidence on Skills Development and Unemployment between 1994 and 2015

Swilling, M. (1987). United Democratic Front and Township Revolt: South Africa.

Taylor, R and Hoeane, T. 2007 Interpreting the South Africa Election of June 1999, Routledge.

UNDP. (2013). Humanity Divided: Confronting Inequality in Developing Countries. United Nations Publisher

Vanderveen, Z. (2007). Pragmatism and Democratic Legitimacy: Beyond Minimalist Accounts of Deliberation. Penn State University, Vol.21, No.4, pp. 243-258

Venter, A. (1989). South Africa Government and Politics: An Introduction to its institutions. Process and Policies.

Wilson, R.A. (2001). The Politics of Truth and Reconciliation in South Africa: Legitimizing the Post-Apartheid State. Cambridge University Press, UK.

Whitehead, L. (2002). Democratization Theory and Experience. University of Oxford Journals

Bruce,D. (2013). A Provincial Concern: Political Killing in South Africa, South Africa Crime Quarterly, No.45.

Cheteni,P, Moh, G and Yohane, K. (2018). Drug-related and Poverty in South Africa. Cogent Economics \& Finance. https// doi.org 21/11/2020

Buchaman, A. (2002). Political Legitimacy and Democracy. The University of Chicago Press, Vol.112, No.4, pp.689-719

Gibson, J.L. (2006). The Contributions of Truth to Reconciliation: Lesson from South Africa, SEGE Journal of Conflict Resolution. 
Jinadu, A.L. (2005). Explaining \& Managing Ethnic Conflict in Africa: Towards A Cultural Theory of Democracy. Cass Occasional Monograph, No. 15 Centre for Advanced Social Science.

Karodia, M and Soni, P (2016). President Jacob Zuma and South Africa's Finance Crisis: A Machiavellian Debacle. International Business Research Vol.9. No 7

Kersting, N. (2009). Voting Behaviour in 2009 South Africa Election. Africa Spectrum, Vol.44, No.2, pp.125-133.

Pillay, S. (2004). Corruption-the Challenge to Good Governance: A South Africa Perspective. The International Journal of Public Sector Management, Vol.17, No.7, pp. 586-605.

Thesis

Geisller, M.I. (2009). Democratiasation of Russia from Gorbachev to Putin. Unpublished Master Thesis, European Studies.

Working Papers

Ake, C. (1992). Feasibility of Democracy in Africa. Keynote Address at the Symposium on Democratic Transition in Africa and University Exchange.

Anyaoku, E. 1991 Beyond Apartheid Human Resources in a new South Africa, Report of Commonwealth Expert Group Prepared for the Head of Government Meeting, Harare.

Bratton, M. (2004). State Building and Democratisation in Sub-Saharan Africa: Forwards, Backwards, or Together. Afro-barometer, working paper, No 43.

Carbone, G, and Memoli, V. (2012). Does Democratisation Foster State Consolidation? A Panel Analysis of Backward Hypothesis.

Masemola, N.P.K. (2007). Floor-Crossing and its Political Consequences in South Africa. EISA Occasional Paper November 44.

\section{Articles}

Dawes, A. (2008). Political Transition and Youth Violence in Post-apartheid South Africa: In Search of Understanding. University of Cape Town. https/www.resarchgate.net/publication. 21/11/2020

Ginsburg, D. (1999). The Democratisation of South Africa: Transition Theory Tested, Article. 